\title{
Student teachers' perceptions of teaching practice assessment in Egerton University, Kenya
}

\author{
Patricia Wambugu, Anne Barmao, Joel Ng'eno \\ Department of Curriculum, Instruction \& Education Management, Egerton University, Njoro, P.O. Box 536-20115 Egerton, Kenya
}

\section{Email address:}

patriwa@yahoo.com(P. Wambugu),barmaoanne@yahoo.com(A. Barmao),jkngeno@yahoo.com(J. Ng’eno)

\section{To cite this article:}

Patricia Wambugu, Anne Barmao, Joel Ng'eno. Student Teachers' Perceptions of Teaching Practice Assessment in Egerton University, Kenya. Education Journal. Vol. 2, No. 4, 2013, pp. 169-175. doi: 10.11648/j.edu.20130204.20

\begin{abstract}
Teaching practice is a key component of the undergraduate teacher training programme. It is during this period that the student teacher gets to translate the skills and theory learnt into reality through actual classroom teaching. Since the inception of the Bachelor of Education (Science), Bachelor of Education (Arts) and Bachelor of Science (Agriculture Education) programmes at Egerton University, the teacher trainees have always proceeded for teaching practice at the end of their third year of training. Although research on teaching practice in Egerton University has been done, there is need to replicate and investigate the current state of the perceptions of student teachers towards teaching practice assessment. It was with this in mind that the study was undertaken. The study investigated the student teachers' perceptions of teaching practice assessment. Three teaching practice zones namely; Kericho/Bomet, Uasingishu,/Keiyo and Nyeri/Kirinyaga were randomly selected. From the zones 68 students were selected using stratified random sampling technique based on gender and subject area specialization. The study adopted descriptive survey research design and it used a questionnaire which had a reliability coefficient alpha of 0.906 to collect data. The collected data was analyzed using both descriptive and inferential statistics. The results showed that the student teachers' perceptions towards teaching practice assessment were favorable. The findings also indicated that there were no statistically significant differences in their perceptions by area of specialization. However there was a statistically significant difference in perceptions of teaching practice between male and female student-teachers at alpha level of 0.05 . The findings may be used to enhance teaching practice assessment.
\end{abstract}

Keywords: Student Teacher, Perception, Teaching Practice Assessment, Egerton University

\section{Introduction}

Teaching can be defined as giving lessons to students in an institution of learning. It can also be defined as showing students how to do something so that he/she will be able to do it themselves in addition to making them to feel or think in a different way (Honby, 2006). From this definition, teachers have enormous responsibilities of helping their learners learn new things through provision of knowledge, demonstrations for them to see thus changing learners' attitudes in desired directions. Therefore teachers are expected to tailor their teaching to meet the learner's level and use their daily routine experiences and activities to help them learn (Hamdan \& Hajooj, 2006). Academically and professionally qualified teachers are expected to dedicate a lot of their time and effort to develop and reinforce their students' creative thinking. This creates in their learners positive attitudes towards what is being taught, demonstrated and illustrated regardless of its challenges.
Besides, it will help learners develop properly their personalities and hobbies to become efficient citizens in future.

Shahin and Alexander (2006) assert that qualified and competent teachers have critical roles to play in determining their country's development and prosperity. These assertions have been supported by Bisher (2005) who argues that teachers are indispensable despite new developments in education such as modern teaching aids to facilitate the teaching and learning process. They play critical roles of interacting and communicating with their learners. These roles are necessary since they assist in guaranteeing the achievement of appropriate outcomes. This is further illustrated by Al-magableh (2010) who argues that a well trained teacher can promote and simplify knowledge for students taking into account their varied social and cultural backgrounds and individual differences. It is therefore inevitable for teacher educators to focus on student teachers' pre-service training. This training helps 
the trainees to acquire and develop purposeful, scientific experiences in advance. Such experiences may help student teachers develop their own potentials which will equip them to perform their future roles as teachers with a lot of precision (Mostafa, 2005). These potentials include skills in lesson planning, visualizing, class control, critical thinking, decision making and problem solving. Teaching practice provides an opportunity for student teachers to put into practice these skills before they begin to work as professionals (Alsaid, 2001; Bhargara \& Pathy, 2011).

Chen and $\mathrm{Mu}$ (2010) in their cross-national comparison of pre-service teacher education and curriculum study in China found out that pre-service teacher training programmes cannot be complete without an effective practicum programme where student teachers' go to the field and face the various classroom related situations and taking responsibility for each one of them (Aljasar \& Altamar, 2004). During this period they may successfully start preparing and planning for their lessons, perform teaching and assess their students. A teacher requires practice in using the skills involved in teaching before teaching in the real classroom context. A good teacher should be able to demonstrate and practice various teaching skills and behaviors. Teachers must see how ideas are connected across fields and with everyday life. The deep understanding of the subject matter will provide a foundation for content knowledge which will enable the teachers to make ideas accessible to their learners. Teaching practice component aims at improving confidence, putting theory into practice, learning about student behavior, testing knowledge of subject matter, receiving constructive criticism, discovering teaching strengths and weakness and developing a core set of pedagogic values to which a professionally competent teacher adheres to.

Teaching Practice plays a significant role in formation of perception of pre-service teachers, regarding their roles and responsibilities as professional teachers. Primarily, B.Ed teaching practice invites the student-teachers to exercise all the skills learned in a real classroom situation (Qazi, Rawat, Sharjeel \& Devi, 2008). Teaching practice will be the time that trainee teachers will get to work with experienced teachers. This is a crucial step in learning to be an effective teacher. It is also the time for trainees to put into practice the theories that they have learned in their course. Learning to teach typically involves spending considerable time in schools participating in field experiences of varying lengths, the staples of teacher preparation programs. (Wilson, Floden \& Ferrini-Mundy 2001).Teaching practice also provides a multi-source feedback to the teacher trainees regarding their activities in the cooperating schools. The schools principals will orient observe and evaluate them. They will also obtain academic feedback from experienced specialists, supervisors, cooperating teachers and other student teachers in the same school (Al-magableh, 2010).

It is important to note that problems experienced in teaching practice may influence the professional qualifications of the student teachers. Al-magableh (2010) identified some of the problems that learners are likely to encounter .These problems include lack of visual aids, a large number of students in class, lack of working space for student teacher and lack of references. Almikhlaphi (2005) in a study conducted at University of Ebb identified poor supervision, short period of teaching practice and having a theoretical rather than a practical programme as some shortcomings of teaching practice. He recommended that more practice should be the centre of the training rather than making classroom teaching theoretical. Aljasar and Altamar (2004) did an evaluation of the teaching practice programme in Kuwait University from student teachers perspective. The researchers concluded that the administrative roles performed by the training team and cooperative schools were sources of problems for trainees. In contrast, Abo Nimreh (2003) identified teaching practice problems and went further to find out the influence of gender and specialization on them. The researcher found no problems in teaching practice that relates to its organization and cooperative school. However, he found problems relating to the supervisor and cooperative teachers. Supervisor related problems included abandoning student teachers when they start practicing teaching, not checking their lesson plan books and being busy with students in class while students' teachers are engaged in teaching the class. As regards cooperative teachers the researcher found that they did not offer the trainees any help and were not happy to be observed by the student teacher when teaching. This therefore calls for an orientation course for cooperative teachers to be based on mutual respect. Further in a study of student teachers perceptions towards teaching practice assessment in Masvingo educational region Zimbabwe, Chirese and Chireshe (2010) found that there were no gender differences in students' teachers' perception of teaching practice assessment mark as a true reflection of their performance.

There are several studies which have been conducted on teaching practice and area of specialization. Bishir (2005) while studying teaching practice programme of teacher education in the University of Ebb found that the programme required overhauling since it only met the needs of the secondary cycle while ignoring the primary cycle. Khasawneh (2002) examined the efficiency of teaching practice of physical education teachers at Mu'tah University. The study found that the extent to which cooperative teachers developed student teachers' teaching skills was moderate. In another study by Alnaji (2000) who conducted a survey of graduates in various specializations on the importance of teaching skills and the extent to which they acquired them in teaching practice at Mu'tah University. The findings indicated that the extent to which the graduates acquired such skills was moderate. The researcher attributed this to fewer visits to schools by supervisors so as to ensure that cooperating teachers carried out their responsibilities rightly and that student teachers strictly followed the training schedule. From these studies it is clear that supervisors need to carry out their 
responsibilities properly in following closely the activities of both cooperating teachers and student teachers for effective attainment of teaching practice goals.

Diab (1999) conducted a study on student teachers' attitudes towards teaching practice and supervisor as critical in determining the extent to which the trainees get involved in the teaching process. The study found that student teachers' attitudes towards the following were positive: supervisor, time allocated for training, the extent of follow up by supervisor and having more than one cooperating teacher. Some problems were particularly identified by the study. These include: transportation, lack of teaching aids in the cooperative schools, student teachers not being invited to staff meetings, inability to access the school library, lack of interaction with colleagues and principals' reluctance to solve their training related problems. This led to trainees feeling that they are strangers in the schools. Hence they develop feelings of restlessness and skepticism. Therefore it is important to identify student teachers' perceptions of teaching practice assessment since such feedback may assist a lot in identification of areas in the programme requiring more attention and which needs to be amended so as to achieve its objectives. Almageedi (1988) in a study at King Faisal University found that teaching practice appeared to be more successful in female schools than in male schools. It was found to be particularly successful in terms of the roles played by the supervisor, cooperative teachers and principals. In general, the student teachers' attitudes towards the programme were positive implying that the training was efficient. It may also imply that the same is more efficient in all female schools than in all male schools.

In a study on anxiety towards teaching practice conducted at Ein Shamis Universty, Radwan (2001) confirmed that there was a correlation between level of anxiety and teaching practice related problems. The researcher argues that it is important to consider the psychological characteristics of the trainees together with the educational, administrative and organizational issues. However, the researcher failed to indicate exactly which problems had a relation with teaching practice and the direction of relationship.

Studies conducted on efficiency of the teaching practice training programme and the extent to which they guarantee the professional qualifications of the student teachers have suggested certain measures. Some of these measures include designing the programme so that it fulfills its objectives with promising outcomes. In one such study, Alsa'eed (2006) suggests a period of an orientation for student teachers' before initiating the training process. During the orientation, student teachers' professional needs will be identified. In addition, he recommended an increase in time for micro-teaching and an amendment of the evaluation system. However, the researcher failed to provide detail on the activities to be undertaken during orientation and the criteria for choosing supervisors. Mostafa (2005), in her evaluation of teaching practice programme at Alsoweas Canal University concluded that it was effective in developing student teachers' classroom performance. She suggested that to improve its efficiency further then there was need to focus on professional qualifications of trainees, preparation of teachers' guides and implementation of information technology. A study conducted in Egerton university investigating the postgraduate diploma in education (PGDE) students' perception of the role of practicing schools and university supervisors during teaching practice, indicated that student teachers valued the assistance and advice given during assessment by the supervisors and the schools (Wachanga, Keraro \& Githua, 2001).

It is therefore clear that teaching practice plays an important role in pre-service teacher training. If the teaching practice is executed rightly and effectively then it will assist in producing high quality professionally qualified teachers. Such teachers will be able to play active roles in the development of the teaching process, accommodate rapid educational changes and novel advancements in curricular and instruction. Therefore, teaching practice programmes require frequent revisions and close scrutiny to ensure that its aims and objectives are achieved and that it is being carried out appropriately. As such the current study was carried out in response to this need. The study focused on the Student teachers' perceptions of teaching practice assessment at Egerton University, Kenya.

Egerton University has three pre-service teacher education programmes. They include Bachelor of Education (Bed) Arts and Science and the Bachelor of Science in Agriculture Education and Extension (AGED). All the pre-service teacher education programmes comprises the theoretical and practical components. The practical component is the teaching practice which is undertaken by the student teachers at the end of their third year of training. The teaching practice lasts for one school term which is approximately 14 to 16 weeks. During this period, student teachers are expected to prepare, plan, teach and interact with students and teachers in the course of their day to day activities in their teaching practice schools. The organization and management of the programme is as follows; cooperative schools are spotted by the teaching practice coordinators in the various regions, then students are allocated to appropriate schools in light of their preferences and social circumstances. Once the student teachers report in the schools for teaching practice, they are frequently followed up and assessed by a team of lecturers specialized in teacher education. Each student teacher is expected to be assessed in at least three lessons during the term where lecturers provide feedback at the end of every assessment.

\section{Purpose of the Study}

The study focuses on student-teachers' perception of teaching practice assessment at Egerton University, Njoro, Kenya. 


\subsection{Objectives of the Study}

1. To establish Egerton University student-teachers' perceptions of teaching practice assessment.

2. To determine whether there are significant differences in Egerton University student-teachers' perceptions of teaching practice assessment by gender

3. To determine whether there are significant differences in Egerton University student-teachers' perceptions of

\subsection{Research Question}

- What perceptions do Egerton University studentteachers' have of teaching practice assessment

\subsection{Hypotheses of the Study}

1. There is no statistically significant difference in perception of teaching practice assessment between male and female students of Egerton University.

2. There are no statistically significant differences in perception of teaching practice assessment among Bachelor of Education (arts and science) and Bachelor of science in Agriculture Education and Extension students of Egerton University

\section{Methodology}

This study employed a descriptive survey research design. It is always necessary that before any progress can be made in solving a problem, a description of the phenomena be done. Description is done with intent of making improvement of a situation. In the present study the researchers wanted to assess student teachers' perception of teaching practice exercise at Egerton University, Kenya with intentions of identifying aspects of the programme that needs improvement and make recommendations for the same to the management. In addition, the design was chosen so that generalizations can be made from the teaching practice assessment by area of specialization.

samples representing the population (Creswell, 2005).

The population for the study consisted of all the third year Bachelor of Education (Arts and Science) and Bachelor of Science (Agriculture Education and Extension) students of the faculty of education and community studies. Three teaching practice zones out of seven were randomly selected. A stratified random sample of respondents was made taking into account their gender and area of specialization. A total of sixty eight student teachers successfully responded to the questionnaire at the end of their last teaching practice assessment.

A Student Teachers Perception Questionnaire consisting of twenty items was used to collect the study data. The questionnaire consisted of two sections; the first part provided the demographic information and the second part consisted of items about student teachers perception of teaching practice assessment. The items were designed in a five point likert scale. The researchers gave levels of likert scale numerical values to estimate the extent of agreement with statements in the questionnaire. 5 was given for strongly agree (SA), 4 for agree (A), 3 for undecided (U), 2 for disagree(D) and 1 for strongly disagree (SD).The content validity of the questionnaire was ascertained by a team of three curriculum and instruction experts at Egerton University's faculty of education and community studies. The instrument was then pilot tested in one teaching practice zone that did not take part in the study. A reliability coefficient of 0.906 using Chronbach's alpha coefficient was obtained. This was within the acceptable threshold in social sciences. During data analysis, the responses from the questionnaires were coded, scored and then analyzed using both descriptive (means and standard deviations) and inferential (t-test and ANOVA) statistics. Table 1 provides the mean scores and standard deviation of student teachers responses for each item.

\section{Results and Discussion}

Table 1. Student teachers 'perception of Teaching Practice (TP) assessment by Item

\begin{tabular}{llll}
\hline & N & Mean & Std. Deviation \\
\hline The assessment period of teaching practice was too long & 68 & 2.5294 & 1.26338 \\
I was always nervous during the assessment & 68 & 2.1912 & 1.24897 \\
I was confident during assessment & 68 & 4.4853 & .78213 \\
The assessor found me prepared & 68 & 4.5441 & .70040 \\
I was satisfied with the roles played by the supervisors & 68 & 4.5294 & .65724 \\
I always got feedback of my performance at the end of the lesson & 68 & 4.3824 & .91471 \\
I did not like being assessed, without being informed & 68 & 2.6029 & 1.43662 \\
I always got guidance from the assessors on teaching methods & 68 & 4.2500 & .85300 \\
The assessor provided me with opportunity to reflect on my teaching & 68 & 4.2059 & .65924 \\
The assessment helped me to be a better teacher & 68 & 4.6176 & .82912 \\
The assessment made me hate teaching as a career & 68 & 4.6029 & .71529 \\
The role played by the supervisors was not satisfactory & 68 & 4.3235 & .93747 \\
\hline
\end{tabular}




\begin{tabular}{llll}
\hline & N & Mean & Std. Deviation \\
\hline I found it difficult to manage my class during assessment & 68 & 4.1618 & 1.25318 \\
Class management was easy during assessment & 68 & 4.3529 & .72821 \\
The assessment helped me to improve my teaching method & 68 & 4.5147 & .78213 \\
The assessment helped me to get new ideas on teaching & 68 & 4.4412 & .76064 \\
The assessment discouraged me from being keen on teaching effectiveness & 68 & 3.9853 & 1.27540 \\
I was given appropriate support towards assessment by the students & 68 & 4.4412 & .69930 \\
I enjoyed the assessment period & 68 & 4.2794 & .91171 \\
Valid N (listwise) & 68 & & \\
\hline
\end{tabular}

The results of table 1 indicate that generally student teachers' had favorable perceptions of teaching practice assessment. These findings agree with those of Mostafa (2005) who found that the teaching practice programme at Alsoweas Canal University was effective in developing student teachers' classroom performance. Further, the findings agree with those of Almageedi (1988) at King Faisal University who found that the teaching practice programme was effective as indicated by the student teachers' positive attitude towards it. In addition Diab (1999) in his study on student teachers attitudes towards teaching practice and supervisor as critical in determining the extent to which the trainees get involved in the teaching process. The study found that student teachers' attitudes towards the following were positive: supervisor, time allocated for training and the extent of follow up by supervisor. The current study findings indicate that the student teachers were generally satisfied with roles played by the supervisors and felt that the period of the training was sufficient. The same findings also agree with Radwan (2001) in his study conducted at Ein Shamis University. The study confirmed that there was a correlation between level of anxiety and teaching practice. The current study has also found that the student teachers were not nervous during assessment and did not like being assessed without prior knowledge of the same. Table 2 presents the descriptive results of student teachers' perception of teaching practice assessment by gender.

Table 2. Student-teachers' perception of teaching practice assessment by gender

\begin{tabular}{ccccc}
\hline Gender & N & Mean & $\begin{array}{c}\text { Std. } \\
\text { Deviation }\end{array}$ & Std. Error Mean \\
\hline Male & 38 & 4.1184 & .36194 & .05871 \\
Female & 30 & 3.9550 & .30039 & .05484 \\
\hline
\end{tabular}

Results in Table 2 indicate that both male and female student-teachers had a favorable perception of teaching practice assessment. However, male student-teachers had a more favorable perception of teaching practice assessment than their female counterparts. To determine whether the difference in mean scores were significant a t-test was computed and the results are indicated in Table 3

Table 3. Gender differences in Student-teachers' perception of teaching practice assessment

\begin{tabular}{ccccc}
\hline & $\mathbf{t}$ & df & $\begin{array}{c}\text { Sig. } \\
\text { (2-tailed) }\end{array}$ & $\begin{array}{c}\text { Mean } \\
\text { Difference }\end{array}$ \\
\hline $\begin{array}{c}\text { Equal variances } \\
\text { assumed }\end{array}$ & 1.990 & 66 & .050 & .16342 \\
$\begin{array}{c}\text { Equal variances not } \\
\text { assumed }\end{array}$ & 2.034 & 65.812 & .046 & .16342 \\
\hline
\end{tabular}

Critical values $\mathrm{t}_{(\mathrm{df}=66, \alpha / 2=0.025)}=1.984$

The calculated value of $\mathrm{t}(1.990)$ is more than the critical value of $\mathrm{t}(1.984)$ two tailed test which shows that there is a statistically significant difference in student teachers perception of teaching practice by gender in favor of the male student teachers at 0.05 level of significance. The null hypothesis which stated that there is no statistically significant difference in perception of teaching practice assessment between male and female students of Egerton University was therefore rejected. This implies that the male students were more comfortable during teaching practice assessment than their female counterparts. These findings seem to agree with Husen and Postlethwaite (1991) who argued that males are field independent while females are field dependent. This implies that male students are not sensitive to the environment around them as compared to females. It therefore means that male student teachers were not affected by the presence of supervisors in their classes during assessment as compared to females. However, the findings of the study disagrees with those of Almageedi (1988) who found that student teachers felt that teaching practice was more successful in all female schools than in all male schools. Chireshe and Chireshe (2010) also disagrees with the above findings by confirming in their study that there were no significant gender differences in students teachers' perception of marks awarded during teaching practice as a true reflection of their performance. Table 4 presents the mean scores of student teachers perception of teaching practice assessment by subject specialization. 
Table 4. Mean scores of Students- teachers'perceptions of teaching practice assessment by subject specialization

\begin{tabular}{cccc}
\hline & N & Mean & Std. Deviation \\
\hline Science & 39 & 4.0859 & .34046 \\
Arts & 11 & 3.9864 & .23462 \\
Aged & 18 & 3.9972 & .40673 \\
Total & 68 & 4.0463 & .34363 \\
\hline
\end{tabular}

The results of table 4 show the mean scores of studentteachers' perception of teaching practice assessment by area of specialization. The results indicate that the Bachelor of Education science had a more favorable perception than the other two areas of specialization. To determine whether the difference in mean scores were significant, one way ANOVA was computed and the results are indicated in Table 5

Table 5. Differences in Students- teachers 'perceptions of teaching practice assessment by subject specialization

\begin{tabular}{cccccc}
\hline & Sum of Squares & df & $\begin{array}{c}\text { Mean } \\
\text { Square }\end{array}$ & F & Sig. \\
\hline Between Groups & .144 & 2 & .072 & .603 & .550 \\
Within Groups & 7.768 & 65 & .120 & & \\
Total & 7.912 & 67 & & \\
\hline
\end{tabular}

Critical values $\mathrm{F}_{(\mathrm{df}=2,65, \alpha=0.05)}=3.07$

The ANOVA results show that there is no significant difference in student-teachers perception of teaching practice assessment by area of specialization. This means that all the student teachers were equally satisfied with teaching practice assessment regardless of subject area specialization. These findings seem to agree with those of Alnaji (2000) who surveyed graduates of various specializations with regard to the importance of teaching skills and the extent to which they acquired them in the teaching practice exercise at Mu'tah University. The researcher found that the extent to which they acquired teaching skills was moderate for all of them irrespective of area of specialization. This scenario could be attributed to the fact that all the students teachers surveyed were from the same University and they all went through a similar programme and assessment by the same supervisors. However, the findings of the study contradicts those of Bishir (2005) who found that the teaching practice programme at the University of Ebb only met the needs of the secondary cycle of education and ignored those of the primary cycle.

\section{Conclusions and Recommendations of the Study}

\subsection{Conclusions}

The following conclusions were drawn from the research findings

1. Egerton University student-teachers have a favorable perception of teaching practice assessment

2. There is a statistically significant difference between Egerton University's male and female student teachers' perception of teaching practice assessment in favor of males.

3. There are no statistically significant differences in Egerton University student teachers' perception of teaching practice assessment by area of specialization.

\subsection{Recommendations}

In view of the conclusions, the following recommendations were made;

1. A comparative study should be done on perception of teaching practice in different universities in Kenya.

2. A study should be carried out on the role of cooperating teachers in mentoring student teachers.

3. An observational study on student teachers classroom practices should be done.

4. Student teachers need to be informed before assessment.

\section{References}

[1] Abo Nimreh, M. 2003. Problems Facing Students in the Educational College (ANRAWA-Amman) enrolled in the Practicum. Student Teachers Journal,182,69-85

[2] Al-magableh,A.M.F 2010. An Evaluation of English Practicum at Yormuk University from Cooperative Teachers and Student- Teachers Perspectives. International Journal of Language Studies(IJLS), vol.4(4),263-300

[3] Almageedi, H. 1988. An Evaluation of the Practicum in College of Education at King Faisal University. Journal of Arab University Union, 33,169-222.

[4] Almikhalafi, M. 2005. A Suggested Programme for Developing Practicum in the School of Education at Ebb University. University Researcher, 8,133-154

[5] Alnaji, H. 2000. An Evaluation of Pre-service Practicum at Mu'tah University from Graduates Perspectives. Mu'tah for Studies and Research,15 (3),179-205

[6] Alsa'eed, S. 2006. Practicum and Preparing Future Teachers. Studies in Curriculum and Instruction, 114,195-239.

[7] Alsaid,M. 2001. Efficiency of a Suggested Program for Developing Art Education Student- Teachers' Critical Thinking and its Influence on the Outcomes of the Teaching Process. Studies in Curricula and Instruction,71,83-221

[8] Bhargara A. \& Pathy M. 2011. Perception of Students 
Teachers about Teaching Competencies. American International Journal of Contemporary Research vol. 1(1) $77-81$

[9] Bishir, Y. 2005. A Suggested Educational Perspective for Teacher Education and Development in the School of Education at University of Ebb. University Researcher, 8,93124

[10] Chen, J. \& Mu, Z. 2010. The Cross-National Comparison of Pre-service Mathematics Teacher Education and Curriculum Structure. Journal of Mathematics Education vol. 3(1) 119136.

[11] Chireshe, R. \& Chireshe, E 2010. Student Teachers Perception of Teaching Practice Assessment. South African Journal of Mathematics Education Vol. 3(1) 119-136.

[12] Diab,T. 1999. Student- Teachers Attitudes Towards Practicum at Jordan University: An Evaluative Study. Divvasat, Education Sciences, 26(1), 142-164

[13] Hamdan,M\& Jahjooh A.Y.2006. A Suggested Model for Developing Practicum for Students of Primary Cycle Department in the School of Education at Alagsa University. Studies in Curricula and Instruction, 114,195-239.

[14] Hornby, A.S (Ed.). 2006. Oxford Advanced Learner's Dictionary International Students Edition ( $7^{\text {th }}$ ed). London: Oxford University Press

[15] Husen, T \& Postlethwaite, T.N. 1991. Cognitive Styles. In The international encyclopedia of education vol.2 pp. 868-
871 New York pergamon press.

[16] Idris, N., Cheong, L. S., Nor, M. M., Razak, A. Z. A., \& Saad, R. M. 2006. The Professional Preparation of Malaysia Teachers in the Implementation of Teaching and Learning Mathematics and Science in English. Eurasia Journal of Mathematics, Science and Technology Education 3 (2): 101110

[17] Jahin \& Alexander 2006. Saudi EFL Student Teachers' Beliefs about Language Learning: The Impact of a Preservice Teacher Education Programme. Studies in Curriculum and Instruction, 110, 1-30.

[18] Khasawneh, M. 2002. Efficiency of Maths Cooperative Teacher in Developing Student Teachers Performance. Mu'tah for Studies and Research, 17(5):113-138.

[19] Qazi W., Rawat K.J., Sharjee M. Y., Devi M. S. 2008. Teacher Perception about Implementation Strategy of B.Ed Teaching Practice in Real School. The S.U. Journal of Education. Vol. XXXVIII, 2008-09, Pp. 54-76

[20] Wachanga S. W., Keraro F. N. \& Githua B. N. 2001. Towards the Improvement of Teaching Practice: The Role of Practice Schools and University Supervisors from Students' Perspectives. Journal of Education and Human Recourses 1 (1): $90-104$

[21] Wilson, S. M., Floden R. E. \& Ferrini-Mundy J. 2001 Teacher Preparation Research: Current Knowledge, Gaps, And Recommendations center For the Study of Teaching and Policy University of Washington 